\title{
[討 論]
}

\section{「養生温度の変動がコンクリート強度発現に及ぼす影響 一積算温度方式の適合性に関連して一」に対する討論}

（大井孝和著，日本建築学会論文報告集・第 307 号，昭和 56 年 9 月掲載）

正会員笠 井 芳 夫*

貴殿の上記論文のうち 4 頁左カラム下から 4 行目より 小生の研究を引用していただき光栄に存じます。このう ち右カラム下から 3 行目より，次のような表現がありま す。

すなわち，

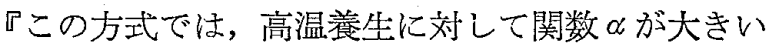
負值をとり，本来この值がもっていた物理的意味を放 棄することになる。』

とありますが，これはどういうことを意味するので しようか？ 貴殿の論文中の「(1) 式：JASS 5.12 に 示されたといら式

$$
M=\left({ }^{\circ} D D\right)=\int_{T_{0}}^{T_{1}}(\theta-\alpha) \alpha_{t}
$$

この式に扮いて $\alpha=-10^{\circ} \mathrm{C}$ と拉くと

$$
M=\left(^{\circ} D D\right)=\int_{T_{0}}^{T_{1}}(\theta+10) d t
$$

となっていますが，小生の式は， $1^{\circ} \mathrm{C}$ 程度から $40^{\circ} \mathrm{C}$ ま でに適用するもので, $M=\left(T^{\circ} T\right)=\int(\theta+\alpha) d t$ となっ

*日本大学 教授・工博

(昭和 56 年 12 月 21 日原稿受理日)
ております。のが偪をとるということは考えておりませ h。

次に小生の $T^{\circ} T$ 関数では, 貴論文に扔ける温度效果 の補正項 $B=A\left({ }^{\circ} D\right)^{2}+B\left(^{\circ} D\right)+C$ といらょうな二次式 加らなる補正を行わなくとも， $1^{\circ} \mathrm{C}$ 程度加ら $40^{\circ} \mathrm{C}$ 程度 まで適用できます。

また貴論文において指摘された“高温養生に対して関 数 が大きい負值をとり”, の件ですが，小生の論文で は $40^{\circ} \mathrm{C}$ 養生に打いて $\alpha=10^{\circ} \mathrm{C}$ となり, ${ }^{\circ} \mathrm{T}$ は $50^{\circ} \mathrm{C}$ と なるのみで, JASS 5 の式で $40^{\circ} \mathrm{C}$ まで適用するものと しても ${ }^{\circ} D=40+10=50^{\circ} \mathrm{C}$ となります。このように，高 温において かが特に大きい值をとることはありません。

最後に，貴論文中における “本来この值めがもってい た物理的意味”について貴殿の見解をお聞かせいただき たく存じをす。以上，貴論文のうち，小生の論文に関わ る部分について見解を述べましたが，先に取上げあした “この方式……することになる”。という表現について再 検討をいただければありがたく存じます。

\section{笠井芳夫博士のご討論に答えて}

正会員大 井 孝 和*

最初に箨者のつたない論文中で既に定まった評価を得 ておられる $T^{\circ} T$ 方式のご研究について十分な説明がで きなかった非礼を拉詑びすると共に，ご指摘の個所につ いて筆者の考えを述べる機会が与えられたことを感謝す る。

ご討論の内容は, $T^{\circ} T$ 方式の原式 $f_{c}=a\left(T^{\circ} T\right)^{n}$, ${ }^{\circ} T={ }^{\circ}(\bar{t}+\alpha), \quad \alpha=|\bar{t}-20| / m$ を撆諭文本文中の p. 4 右 下から 6 行目のよらな形に畫に変えた理由, すなわち原 文中で正值として示されている $\alpha$ 項をわざわざ $+\alpha=$

* 愛知工業大学，教授・工博

(昭和 57 年 3 月 16 日原稿受理日)
ー ( $\propto$ ) と書く立場をとった理由を問うものと考えられ る。

[1] 同様の畫き変えは JASS 5.12.1 式と本文 (1) 式の間でも行っているが，こ杣笔者の独創ではなく， 次のような理由から一般に許容された表現である。例え ば，日本建築学会「寒中コンクリート施工指針案・同解 説」 1 節 p. 25 では, Saul がその論文の欄外ノートと して, “-10 $10^{\circ}$ を $0^{\circ}$ とする温度 $(\theta+10)$ をもって整理 するのが一つの整理方法ではないか”と述べていること が引用されている。また，かつて我国で注積算温度方式 について温度時間面積勃果ということがいわれ， $\alpha=$ 
$-10^{\circ} \mathrm{C}$ を原点とする図形的説明がなされたが，その説 明は当時の多くの聴衆に強い印象を与えたと記憶してい る。

実際，この図形的説明は以後の積算温度方式の諸理論 において基本的概念として継承されるほじ重要なものて あったが，その考方方に従って積算温度の積分演算を時 間軸に沿って行らとき, $0^{\circ} \mathrm{C}$ に扮いて ${ }^{\circ} D$ 屯 ${ }^{\circ} T$ \& 0 に はならず， $0^{\circ} \mathrm{C}$ がコンクリート羡生に対して何ら特別な 意味を持たないとすれば， ${ }^{\circ} D$ あるいは。 $T$ が 0 になる ときの摂氏温度についてその意味を求めようとするのは 当然の成り行きであろう。

そのことを述べた本文 (1) 式の $\propto$ 值に刘する記号説明 は，直接的には参考文献 p. 21 の記述に沿ったもので女 るが， $\alpha$ 值が摂氏温度の単位で表現される限り，このよ らな意味が付与されることは免れないであるうと思われ る。これがあた本文中に㧍いて“本来この $\alpha$ 值がもって いた物理的意味”と呼んだものである。

もっとも，筆者も丁度 $-10^{\circ} \mathrm{C}$ をむてセメントの水 和反态の絶対停止温度と見なすといら主張に賛成してい る訳ではなく，コンクリート工学の立場から $-10^{\circ} \mathrm{C}$ 以 下の養生温度は全く考慮する必要がないといら判断に従 って，JASS 式の形を踏襲したすでである。なお，本文 (1) 式が JASS 式と異なって積分記号 $\int$ のみを用いて いる点に関しては最後に触れたい。

[2] $T^{\circ} T$ 方式に関する筆者の理解の重点 は，指摘 された個所の直前の本文にある。すなわち，本文 p. 4 右下加ら 6 行目には, “笠井の $\left(T^{\circ} T\right)$ そ呼ばれる提案 法，(1）式……に拈ける $\alpha$ 值を変化させることにより養 生温度の效果を補償しょうとするもので，……”南 り， $T^{\circ} T$ 方式においてはこの $\alpha$ 值に積極的な意味が付 与されていること，その点では先駆的に成功した理論で あることを評洒している。

確かに，(T) をひとつの関数と見なすならば( $\alpha$ 值を 関数と考えるのではなく， \& 值の意味が変化するのは 当然であって，このような説明はなたほとんどの積算温 度方式に適用することができる。 $T^{\circ} T$ 方式の湯合はた ぶん “ $20^{\circ} \mathrm{C}$ 基準温度として” 養生温度の効果を表わし た関数であると考光るのが適当であらら。

以上のような理解に加えて，ご指摘の個所のような説 明を本文中に併記した理由は，もとはといえば笠井博士 がご自身の論文でなされている説明にある。すなわち， 参考文献 10） p.9 亿よれば,。“ “養生温度の仮想原点 で $\alpha=|\bar{t}-20| / m$ とする。書加机ている。ある養生温 度の仮想原点に対する位置を求めようとするとき，その 温度の摄氏温度から仮想原点の摂氏温度を引算するのは きわめて自然で注なかそうか。(+人ではなく のように） $T^{\circ} T$ 方式にはそのような解釈を許す余地が あり，また我国の代表的な理論のひとつなのである。
[3] $T^{\circ} T$ 方式の $\alpha$ 項が高温養生において大きい負 值（原式では大きい正值）をとると述べた点に関して は，高温養生と呼ぶときの温度範囲について笠井搏士と 筆者の間に若干のずれがあったものと思われる。笠井博 土がいわれる高温低温とは，通常の建築工事現場におい てよく管理されたコンクリートが遭遇する温度範围内の ことであり，筆者はそのような場合は暑中コンクリート 寒中コンクリートと呼びたいと思う。

セメント化学の分野では, ポルトランドセメントの水 和反応機構は $60^{\circ} \mathrm{C} \sim 100^{\circ} \mathrm{C}$ に至るまで常温の場合と本質 的に変ったところがなく，ただ反応速度が変化するだけ と考えられて招り"，筆者も $-10^{\circ} \mathrm{C} \sim 60^{\circ} \mathrm{C}$ の温度で養 生したコンクリート供試体の微細構造の観察から同様の 見解を抱いている2!。この立場からすれば，高温養生と は少くとも蒸気養生かオートクレーブ養生のような加熱 促進養生を想定するるこになり，もっと端的にいえばポ ルトランドセメントの水和反応機構が常温とは異なる場 合, 寸なわち水酸化カルシウムとシリカの水熱反応が起 るような温度領域を指すことになる。

ご指摘の本文は， $\alpha$ 值を変化させるだけで温度効果を 補償しようとする方式をこのような高温領域まで適用寸 ると無理が生じやすいことを述べたのであって，T T T 方式の適用温度範囲が $40^{\circ} \mathrm{C}$ 以下に抑えられている理由

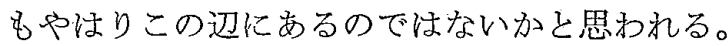

それでは本文 (2)，(3) 式の積算温度， $\beta^{\circ} D D$ 方式は どれくらいの温度範囲に適用できるかといらと，その式 を導いた筆者の $-10^{\circ} \mathrm{C} \sim 60^{\circ} \mathrm{C}$ 養生の実験データによく 適合するのはいらまでもないとして，参考文献 12)，13） などの蒸気養生コンクリートにも適合し，またそれほど 多くの実験データによって検討したわけではないが，ほ ぼ $170^{\circ} \mathrm{C}$ 程度のオートクレーブ養生に至るまで，本質的 な困難なしに僅かな式の変更で適用できる見通しが立っ ている。

[4] $\beta^{\circ} D D$ 方式がこのように広範囲な養生温度に適 合した理由は，先の図形的説明によれば，温度軸を撰氏 温度目盛とせず， $\left(\beta^{\circ} D\right)$ のよらな関数の尺度で表現し た点に帰せら机る。

この温度軸にとられる関数は, 任意の温度におけるコ ンクリート硬化過程の進行速度あるいはセメントの水和 反応速度の（標準温度に斿ける反応速度に対する）比率 を表わすものであり，養生時間の換算率として明快に定 義しらるものである。それ故，たと立温度領域によって セメントの水和反応機構が変化する場合にも，すべての 温度範囲にわたって本質的な困難なしに，適切な関数の 尺度を選ぶことにより対応できることになる。

この関数尺は熱力学的温度 ${ }^{\circ} \mathrm{K}$ で定義してもかまわな い訳であるが，コンクリート工学の立場からは $-10^{\circ} \mathrm{C}$ を下限温度とする $\left({ }^{\circ} D D\right)$ 方式がより適当であると考え 
たことは既に述べた通りである。

[5] $T^{\circ} T$ 方式の最大の特徵は, 積算温度から若材 令コンクリートの強度を推定する目的のために，実験式 としては最も基本的で簡潔な形の推定式を提案されたこ とにあると思われ，その業積は不滅のものである。また 実際に実験データにあてはめてみて，本文図一2 からも わかるように， $0^{\circ} \mathrm{C} \sim 40^{\circ} \mathrm{C}$ の範囲では $\beta^{\circ} D D$ と $T^{\circ} T$ は 最も近い関係にあるが，これは両者の実験データに対す る適合性を互いに保証するものであろう。

ところで等者の提案した $\beta^{\circ} D D$ 方式が $T^{\circ} T$ 方式およ び JASS 5.12.1 式に対して最も大きく相違する点は養 生温度 $\theta$ の定義の変更および時間軸に沿って $\left(\beta^{\circ} D\right) の$ 積分演算を撖密に要求したところにある。

も乙積算温度の計算に㧹いて養生期間中の平均養生温 度もしくは日平均養生温度を用いるならば，その期閒中 の養生温度变動の影響について筆者が論文の表題でもっ
て提起した問題点には全く触れることがない。あの論文 の出発点は確かにそこなのである。筆者としてはあの論 文に意義があるとすれば，積算温度方式の理論を厳密に 展開することによって，養生温度の変動がもたらすその ようなコンクリート硬化の複雑な挙動をよく説明できる ことを示し得たこと，またその説明からコンクリート硬 化過程に対する簡潔なひとつの見解 (モデル化) が導か れること，それをセメント化学に㧈ける反応速度論に対 応するコンクリート工学の理論として位置付けようと努 めたことにあると考えている。

\section{注}

1）例えば，須藤・秋葉，セメントコンクリート No. 398 , 1980.4, p. 44 など

2) Ooi, Morino, Naito, Proceedings of 23 rd J.C.M.R., 1980, p. 225 大井 ·加藤, 日本建築学会東海支部研究報告集, 第 19 号, 1981.2 , p. 1 , p. 5 なぞ 